\title{
Skin Metastasis from a Parotid Neoplasm
}

\section{Eva Fuster Martín ${ }^{1 *}$, Juan Sánchez Jiménez ${ }^{2}$ and Rocio Solórzano Mariscal $^{3}$}

${ }^{1}$ ENT Department, Hospital Regional Universitario de Málaga, Spain

${ }^{2}$ Maxillofacial Department, Hospital Universitario de Jaén, Spain

${ }^{3}$ Pathology Department, Hospital Universitario de Jerez, Cádiz, Spain

*Corresponding Author: Eva Fuster Martín, Sociedad Española de ORL (SEORL),

European Academy of Otology and Neuro-Otology (EAONO), Málaga, Andalucía, Spain.
Received: August 18, 2021

Published: September 27, 2021

(C) All rights are reserved by Eva Fuster

Martín., et al.

\begin{abstract}
Salivary duct carcinomas are rare tumors known for their predominant location in the parotid gland, its aggressive behavior and high rate of recurrence. It resembles pathologically and immunophenotypically to high-grade ductal breast adenocarcinoma. This report presents an additional case of cutaneous metastasis from a salivary duct carcinoma of parotid gland. We have found thirteen more cases in the literature and we have noticed that every case follow a different treatment scheme. The limited number of cases reported in the literature make difficult to design a treatment protocol. However, new emerging clinical studies are comparing gene and protein expression levels between salivary duct carcinoma and breast carcinoma to identify future targeted therapy.
\end{abstract}

Keywords: Adenocarcinoma; Parotid Neoplasms; Neoplasm Metastasis; Skin Neoplasms

\section{Introduction}

Salivary duct carcinoma, described by Kleinsasser., et al. in 1968 for its similarity to ductal breast carcinoma [1], is a rare tumor of the salivary gland with an incidence of 1 - 3\% among all salivary tumors [2]. It usually appears in the sixth decade of life, being more prevalent in men than women $(3: 1.8)$. The parotid is the salivary gland most commonly affected (80\%) and occasionally it can arise in the submandibular gland (8\%) [3]. Pain, swelling and facial palsy are some of the symptoms the patient may complain. It is well known for its aggressive behavior and its high local $(48 \%)$ and distance $(48 \%)$ recurrence. Two thirds of the patients are diagnosed in an advanced stage of the disease, being 42, 40, 30 and $23 \%$ the global survival in five years for stages I, II, III and IV respectively [4].
From the pathological and immunophenotypical point of view, salivary duct carcinoma resembles high- grade ductal breast adenocarcinoma. Both of them share immunoreactivity for androgen receptor, carcinoembryonic antigen, gross cystic disease fluid protein and occasionally human epidermal growth factor receptor 2 (HER2/neu) over expression. The main differences between both tumors are estrogen and progesterone-receptors positive, practically never present in parotid ductal carcinoma [5]. So, despite the fact that both have similar behaviors, it should be highlighted the rarity of cutaneous metastases in salivary duct carcinoma.

Cutaneous metastases are unusual and they appear in 0.7-9\% among all oncologic patients [6]. The frequency of this cutaneous metastatic disease tends to be linked with the primary tumor in 
each sex. In case of salivary duct carcinoma, it has been recorded $2 \%$ in men and $1 \%$ in women [7].

\section{Case Report}

A 67 years old woman was referred to our hospital due to a progressive erythematous plaque on her right neck that looked like an erythema annulare centrifugum. Physical exploration also revealed a $3 \mathrm{~cm}$ lesion in her right parotid gland without signs of facial nerve palsy. Thorough surveys which included skin biopsy, fine-needle aspiration cytology (FNAC) of the parotid lesion and a neck magnetic resonance imaging (MRI) (Figure 1) were performed. The MRI showed lesions within the parotid gland (the biggest one $1.8 \times$ $1.6 \mathrm{~cm}$ ) with aggressive signs suggesting a neoplastic tumor. Also, cervical nodes were evident in I, II, III and IV levels in the right side. The parotid FNAC was positive for neoplastic cells and the pathology result from the skin biopsy was lymphangitic carcinomatosis. With these results, a positron emission tomography- compute tomography (PET-CT) scan was requested, which was negative for distant metastases.

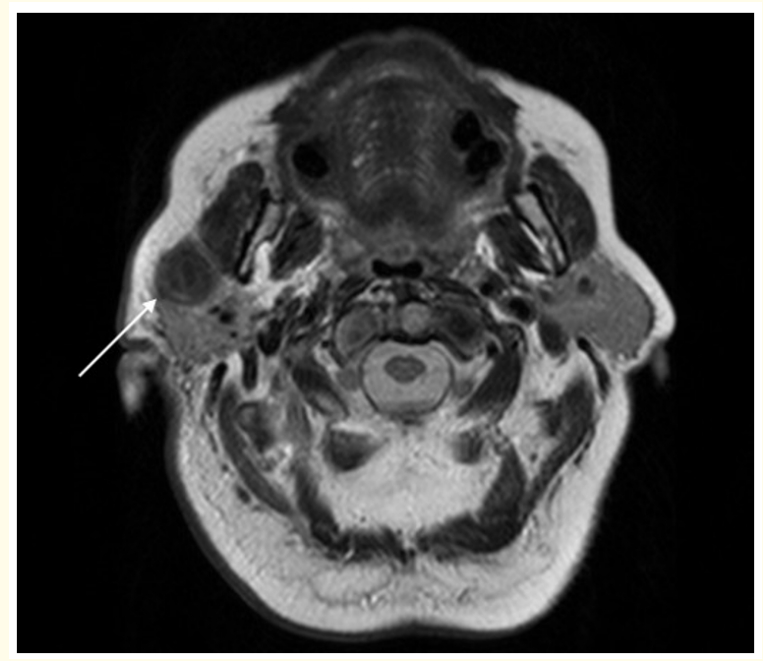

Figure 1: T2 hypointense lesion of $1.8 \times 1.6 \mathrm{~cm}$ that does not enhance with intravenous contrast.

After classifying the lesion as a stage IV (T3N2bM0) in the TNM staging system and discussing the case in the Head and Neck Committee, surgery was decided (radical parotidectomy with modified radical neck dissection).
The pathology of the surgical specimen revealed (Figure 2) a high-grade salivary duct carcinoma with cystic degeneration and comedonecrosis as well as extensive lymphovascular and perineural invasion. The tumor cells were positive to cytokeratin $7, \mathrm{p} 63$ (focal) and carcinoembryonic antigen, versus negativity to cytokeratin 20, Bcl-2, smooth muscle actin, estrogen receptors and progesterone receptors. The Ki67 cell proliferation index was $20-40 \%$. Her-2/neu by fluorescence in situ hybridization (FISH) was negative. It had $100 \%$ positive androgenic receptors. Regarding neck dissection specimen, carcinoma metastases were evidenced in the 43 isolated lymph nodes with extensive lymphovascular invasion.

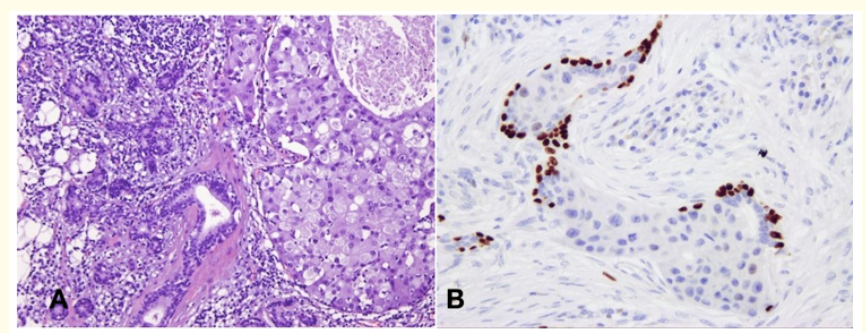

Figure 2: Histological examination. A Infiltration of parotid gland by salivary ductal carcinoma with areas of comedonecrosis. Hematoxylin and eosin (H and E) 10x. B Staining with p63 showing the component of intraductal carcinoma in the glandular tissue. 20x.

Subsequently, she received adjuvant chemoradiation (biweekly Epirubicin and Cyclophosphamide for 4 cycles followed by weekly Paclitaxel for 6 cycles; 42.40Gy in 16 fractions) with complete clinical response and disappearance of dermal infiltrated lesions. However, two months after finishing the adjuvant treatment, the erythematous skin plaque reappeared (Figure 3) and its malignancy was confirmed by biopsy. So then, she began with a new chemotherapy treatment with carboplatin-vinorelbine (Carbo-VNR) for 4 cycles, improvingthe skin lesion, and later anti-androgen therapy (Bicalutamide) was introduced. Two years after surgery, the skin metastasis persisted and, due to patient deterioration, different therapeutic attitudes were established (a third line of chemotherapy with Capecitabine for 6 cycles, a fourth line with Eribulin for 6 cycles and a fifth line with Caelyx for 5 cycles). The disease pro- 
gressed regardless of the different treatments. In the last PET-CT scan, carcinomatous lymphangitis was found in the left upper lobe of the lung, a metastatic lesion in the left iliac bone and another in the left ethmoides. The patient died 5 years after her initial clinical presentation.

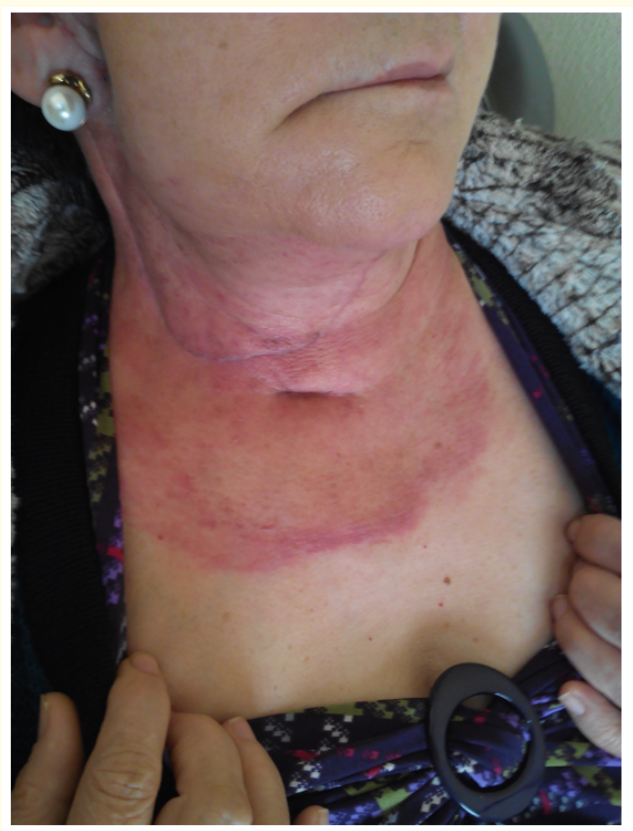

Figure 3: Reappearance of the erythematous and pruritic annular plaque with central regression of skin color on her right neck and chest after surgery.

\section{Results and Discussion}

Malignancies of the parotid gland are uncommon, as are the cutaneous metastases from them. Cutaneous metastases or inflammatory metastatic carcinoma, classically associated with breast cancer since 1886 [8], are characterized by tumor cells predominantly in dermal lymphatics (carcinoma erysipelatoides) or blood vessels (carcinoma telangiectodes). These lesions are often associated with poor prognosis [9] and its appearance after treatment of the primary tumor can be an indication of recurrence.

The clinical appearance is usually an erythematous patch or plaque, although other morphologies have been described such as angiokeratoma-like lesions, bullae, nodules, purpuric violaceous plaques and pseudovesicles. The lack of fever or leukocytosis may suggest the correct diagnosis. However, cutaneous metastases can be unnoticed sometimes by mimicking bacterial infections (like acute paronychia), viral infections (like zoster herpes) or cutaneous tumors (like epidermoid cysts or pyogenic granulomas). They can even appear in hidden tumors yet to be diagnosed, as in our case. Generally, tumors that tend to invade veins often present themselves as cutaneous metastasis in skin sites at a distance from the primary tumor. Cancers that tend to invade lymphatic channels tend to appear in the skin in the later course of the disease overlying the area of the primary tumor [7].

This article reports a rare case of cutaneous metastasis from a salivary duct carcinoma of parotid gland. Thirteen more cases have been published in the literature (Table 1) and, after analyzing them, we have noticed that the most common sites of cutaneous metastases were neck and chest, although it has also been reported in other places like face or scalp. We have also observed that there isn't any protocol of treatment for these cases, probably due to its low incidence. The standard treatment for salivary duct carcinoma is removal of the affected gland (total parotidectomy in this case) and ipsilateral neck dissection, followed by postoperative radiotherapy with or without concurrent chemotherapy. However, none of the cases reported in the literature has undergone the same treatment scheme.

\begin{tabular}{|l|c|c|c|c|}
\hline Source & Age/Gender & Primarytumor & Treatment & Skin Metastasis \\
\hline $\begin{array}{l}\text { Allyson Black., } \text { et al. } \\
{[12]}\end{array}$ & $60 / \mathrm{F}$ & Left parotid gland & $\begin{array}{c}\text { Surgery + radiotherapy; Posterior pal- } \\
\text { liative chemotherapy. }\end{array}$ & $\begin{array}{c}\text { Left pruritic erythematous } \\
\text { rash involving the left pinna } \\
\text { and neck. }\end{array}$ \\
\hline $\begin{array}{l}\text { Juber Hauiji., } \text { et al. } \\
{[13]}\end{array}$ & $83 / \mathrm{F}$ & Right parotid gland & Palliative radiotherapy & $\begin{array}{c}\text { Indurated eruption with } \\
\text { infiltrating nodules and } \\
\text { ulceration on her right neck } \\
\text { and chest. }\end{array}$ \\
\hline
\end{tabular}




\begin{tabular}{|c|c|c|c|c|}
\hline $\begin{array}{l}\text { Jeffrey L. Pollock., et } \\
\text { al. [14] }\end{array}$ & $38 / \mathrm{M}$ & Right parotid gland & $\begin{array}{l}\text { Surgery; chemoradiation for recur- } \\
\text { rent tumor mass (6600rads; metho- } \\
\text { trexate, fluorouracil, cyclophospha- } \\
\text { mide). } \\
\text { Doxorubicin and dacarbazine for the } \\
\text { cutaneous metastasis. }\end{array}$ & $\begin{array}{l}\text { Nodules from the midline } \\
\text { to the right anterior axillary } \\
\text { line in a zosteriform distri- } \\
\text { bution }\end{array}$ \\
\hline Julide Tok., et al. [15] & $62 / \mathrm{M}$ & Left parotid gland & $\begin{array}{l}\text { Chemotherapy (doxorubicin HCL, cis- } \\
\text { platin and cyclophosphamide). After } \\
\text { skin metastases appearance, palliative } \\
\text { treatment. }\end{array}$ & $\begin{array}{l}\text { Round firm papules and } \\
\text { nodules on the scalp }\end{array}$ \\
\hline $\begin{array}{l}\text { Andrea Zanca., et al. } \\
{[16]}\end{array}$ & $76 / \mathrm{F}$ & Right parotid gland & Surgery & $\begin{array}{l}\text { Erysipelas-like inflamma- } \\
\text { tion on the right cheek and } \\
\text { periauricular area }\end{array}$ \\
\hline $\begin{array}{l}\text { Philip R. Cohen., et } \\
\text { al. [5] }\end{array}$ & $71 / \mathrm{M}$ & Left parotid gland & $\begin{array}{l}\text { Surgery + chemoradiation (60Gy; } \\
\text { cisplatin) }\end{array}$ & $\begin{array}{l}\text { Erythematous dermal plaque } \\
\text { from his neck to his upper } \\
\text { abdomen. }\end{array}$ \\
\hline $\begin{array}{l}\text { Philip R. Cohen., et } \\
\text { al. [5] }\end{array}$ & $69 / \mathrm{M}$ & Left parotid gland & $\begin{array}{c}\text { Docetaxel subsequently concurrent } \\
\text { chemoradiation (45Gy and cetux- } \\
\text { imab) }\end{array}$ & $\begin{array}{l}\text { Large hemorrhagic- appear- } \\
\text { ing purpuric dermal plaque } \\
\text { from his right face and neck } \\
\text { to his mid- abdomen }\end{array}$ \\
\hline $\begin{array}{l}\text { Piha-Paul SA., et al. } \\
\text { [17] }\end{array}$ & $73 / \mathrm{M}$ & Unknown & $\begin{array}{l}\text { Surgery, chemoradiation and systemic } \\
\text { chemotherapy with carboplatin and } \\
\text { paclitaxel. }\end{array}$ & $\begin{array}{l}\text { Large ecchymotic area with } \\
\text { partial central clearing from } \\
\text { the neck to the xiphoid } \\
\text { process. }\end{array}$ \\
\hline $\begin{array}{l}\text { Piha-Paul SA., et al. } \\
\text { [17] }\end{array}$ & $70 / \mathrm{M}$ & Unknown & $\begin{array}{l}\text { Docetaxel and radiation with con- } \\
\text { comitant cetuximab. }\end{array}$ & $\begin{array}{l}\text { Large ecchymotic and viola- } \\
\text { ceous area from the neck to } \\
\text { the midxiphoid process }\end{array}$ \\
\hline F.G. Aloi., et al. [18] & $42 / \mathrm{M}$ & Right parotid gland & $\begin{array}{l}\text { Surgery + radiotherapy (6000rads); } \\
\text { Skin metastasis treated with vincris- } \\
\text { tine, cyclophosphamide, Adriamycin }\end{array}$ & $\begin{array}{c}\text { Erythematous plaque on the } \\
\text { right neck }\end{array}$ \\
\hline P.Plantin., et al. [19] & $63 / \mathrm{F}$ & Left parotid gland & $\begin{array}{c}\text { Surgery + Chemoradiation (carbopla- } \\
\text { tin, epirubicin and 5- } \\
\text { fluorouracil) }\end{array}$ & Right facial erythema \\
\hline $\begin{array}{l}\text { Robert A. Schwartz., } \\
\text { et al. [8] }\end{array}$ & $60 / \mathrm{M}$ & Left parotid gland & $\begin{array}{l}\text { Surgery; Recurrent tumor removed; } \\
\text { Skin metastases treated with pallia- } \\
\text { tive radiotherapy (4140rads) }\end{array}$ & $\begin{array}{c}\text { Redness and orange skin } \\
\text { changes }\end{array}$ \\
\hline $\begin{array}{l}\text { Ahmet Eroglu., et al. } \\
\text { [20] }\end{array}$ & $58 / \mathrm{F}$ & Left parotid gland & $\begin{array}{l}\text { Surgery at least three times for recur- } \\
\text { rence. Skin metastases treated by } \\
\text { removal biopsy. }\end{array}$ & $\begin{array}{c}\text { Round and hard mass upper } \\
\text { left parietal region }\end{array}$ \\
\hline $\begin{array}{l}\mathrm{F}=\text { Female, } \mathrm{M}=\text { Male, } \\
\text { Surgery = Parotidec- } \\
\text { tomy and ipsilateral } \\
\text { neck dissection }\end{array}$ & & & & \\
\hline
\end{tabular}

Table 1: Characteristics of salivary duct carcinoma patients with cutaneous metastases. 
Several factors are associated with poor prognosis (male, positive margins, high-grade tumor, perineural invasion, nodal disease, strong HER2 protein expression...). However, new emerging clinical studies are comparing gene and protein expression levels between salivary duct carcinoma and breast carcinoma to identify future targeted therapies for these cases. Some authors like Dalin., et al [10] or Al-Qahtani., et al. [11] suggest that androgen-deprivation therapy could be investigated in the majority of salivary duct carcinomas as well as HER2 inhibition for Trastuzumab therapy due to their improvement of disease-freesurvival and overall survival.

\section{Conclusion}

Salivary duct carcinoma is one of the most aggressive head and neck tumors, which means it needs an aggressive therapy. Local and distant recurrences have been described, although few cases have been reported with cutaneous metastases affectation. It is important that in any patient with a metastatic skin lesion resembling breast carcinoma, carcinoma of the parotid gland should be considered in the absence of a definite primary tumor.

\section{Conflict of Interest}

The authors have no other funding, financial relationships, or conflicts of interest to disclose.

\section{Bibliography}

1. Kleinsasser 0., et al. "[Salivary duct carcinoma. A group of salivary gland tumors analogous to mammary duct carcinoma]". Archiv fur Klinische Und Experimentelle Ohren- Nasen- Und Kehlkopfheilkund 192.1 (1968): 100-105.

2. Xie S., et al. "Salivary duct carcinoma of the parotid gland: A case report and review of the literature". Oncology Letters 9.1 (2015): 371-374.

3. Campos-Gómez S., et al. "Case report: anti-hormonal therapy in the treatment of ductal carcinoma of the parotid gland". BMC Cancer 14 (2014): 701.

4. Jaehne M., et al. "Clinical and immunohistologic typing of salivary duct carcinoma: a report of 50 cases". Cancer 103.12 (2005): 2526-2533.

5. Cohen PR., et al. "The "shield sign" in two men with metastatic salivary duct carcinoma to the skin: cutaneous metastases presenting as carcinoma hemorrhagiectoides". The Journal of Clinical and Aesthetic Dermatology 5.9 (2012): 27-36.

6. Spencer PS and Helm TN. "Skin metastases in cancer patients". Cutis 39.2 (1987): 119-121.

7. Brownstein $\mathrm{MH}$ and Helwig EB. "Metastatic tumors of the skin". Cancer 29.5 (1972): 1298-1307.

8. Schwartz RA., et al. "Inflammatory metastatic carcinoma of the parotid". Archives of Dermatological 120.6 (1984): 796-797.

9. Dequanter D., et al. "Skin metastases from a head and neck carcinoma: a prognostic factor?" B-ENT 1.3 (2005): 113-115.

10. Dalin MG., et al. "Comprehensive molecular characterization of salivary duct carcinoma reveals actionable targets and similarity to apocrine breast cancer". American Association for Cancer Research 22.18 (2016): 4623-4633.

11. Al-Qahtani KH., et al. "Clinicopathological features and treatment outcomes of the rare, salivary duct carcinoma of parotid gland". Journal of Otolaryngology-Head and Neck Surgery 45.1 (2016): 32.

12. "Salivary duct carcinoma metastatic to the skin". Journal of the American Academy of Dermatology 74.5 (2016): AB71.

13. Ha*iji J., et al. "A rare cutaneous presentation of metastatic parotid adenocarcinoma". Australasian Journal of Dermatology 54.2 (2013): e40-42.

14. Pollock JL and Catalano E. "Metastatic ductal carcinoma of the parotid gland in a patient with sarcoidosis". Archives of Dermatological 115.9 (1979): 1098-1099.

15. Tok J., et al. "Cutaneous metastasis from a parotid adenocarcinoma. Report of a case with immunohistochemical findings and review of the literature". The American Journal of Dermatopathology 17.3 (1995): 303-306.

16. Zanca A., et al. "Telangiectatic metastasis from ductal carcinoma of the parotid gland". Journal of the American Academy of Dermatology 28.1 (1993): 113-114.

17. JCO.2011.36.pdf (2011). 
18. Aloi PG., et al. "[Cutaneous metastasis with an inflammatory aspect in parotid carcinoma]". G Ital Dermatol E Venereol Organo Uff Soc Ital Dermatol E Sifilogr. 122.4 (1987): 193-195.

19. Plantin P., et al. "[Cutaneous extension of parotid carcinoma]". Annales de Dermatologie et de Vénéréologie 121.8 (1994): 571-

573.

20. Eroglu A., et al. "Basal cell adenocarcinoma of the parotid gland with rare scalp metastasis: a case report". Turkish Neurosurgery 25.1 (2015): 177-179.

Volume 3 Issue 10 October 2021

(C) All rights are reserved by Eva Fuster Martín., et al. 